\title{
報文
}

\section{シャモット質耐火材料の研究（第三報） 熱間荷重の前後に於ける各種性狀の變化}

\author{
永 井 彰 一 郎 \\ 萬 波 音 太 郎 \\ I. 緒霉
}

前揭第二報に於てはシャモっトと耐火粘士との配合割合、成形法、燒成法等の各種の條件を異にせるシャモ。 ト質耐火材料に關する試亦試驗片に就て各種の比較試驗をなしたる結果を報告したり本報に於ては是等の結果 に基き 2 種の耐火粘士 2 種のシャモットより 4 種のシャモ。ト質鿟火材料圾驗片を製作し之を一定の高溫 度に一定の荷重をなしたる前後に於ける比里、吸水率、氣孔率等の各種の物理的性質の變化を試驗比較して以 つてシャモット及び耐火粘士の性質が如何に是等より製作せらるるシャモット質耐火材料の適否に關係を有寸 るものなるかを試驗㸴したる結果を報告すべし。

此の高溫度の荷重は $1300^{\circ} \mathrm{C}, 10 \mathrm{~kg} / \mathrm{cm}^{2}$ の如くシャモット質酎火材料としては雅がて軟化しかよらんとする $1300^{\circ} \mathrm{C}$ にて而も $10 \mathrm{~kg} / \mathrm{cm}^{2}$ の如き多くの荷重なるを以つて或る種のものは第一報第四圖(本誌 $38,793,1930$ ) の市販耐火䠅瓦の場合の如く著しく嬮縮され變化するもの岕り。倘此の試驗に供したる圾驗片を製作せしシャ モットの中の 1 種は第二報に報告したる工場製品、他の 1 種は 2 種の耐火粘土の中の 1 種より當實驗室に於て 試製しなるシャモャトなり。更に粘士の 1 䅨は前記シャモットの試製原粼なるものと他の 1 種は工場使用品 を直接使用したるものなり。

\section{II. シャモット質耐火材料試驗片の製作}

試驗に供したるシャモット 2 種及び耐火粘土 2 種の化學成分、耐火度、シャモットの細度等の試驗結果は酦 揭第二報の第一及び第二表(本誌、39，103，1931）に示したるものにして倘是等のシャモット及び耐火粘土の 試驗料より各種の配合に依りて耐火材料試驗片の成形、燒成等の方法も亦總べて第二報(本誌、39, 105, 1931) に揭載したる方法に準じて行ひたるるのにして其の諸條件次の如し。

(1) 配合割合 是等 2 種のシャモット、2 種の耐火粘土より得らるべき 4 種の耐火材粼訊驗片のシャモ。 トと酎火粘土との組み合せは次の第一表に示すべし。少シャモットに對する耐火粘土の配合割合は耐火粘土 10\%のものと、25\%のものとを主として選で時に $40 \%$ のものをも製作し是等を區別するために $\mathrm{A}_{10}, \mathrm{~A}_{25}$, $\mathrm{A}_{40}$ 等として記入することとせり。 
第一表 耐火材料試驗片の原粼配合割合

\begin{tabular}{|c|c|c|}
\hline 原 & 料 & 名 \\
\hline 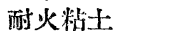 & & シャモツト \\
\hline 州粮 & & 笊三號(復州粘土より試製) \\
\hline 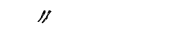 & & 笊二號(工場) \\
\hline E星木節粘土 & & $\begin{array}{l}\text { 兯三號(復州粘土より試製) } \\
\text { 第二號(工場製品) }\end{array}$ \\
\hline
\end{tabular}

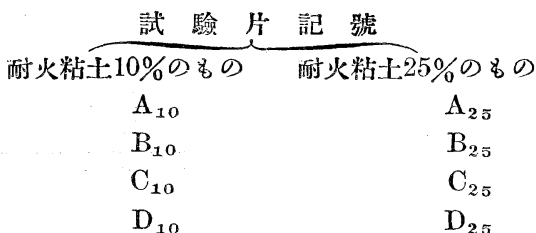

佾此の外に $\mathrm{A}$ と $\mathrm{C}$ とには耐火粘士 $40 \%$ の配合割合のもの $\mathrm{A}_{40}, \mathrm{C}_{40}$ あ あっ此のシャモットの第二號、第 三號とあるは何れる第二堽第一表（本誌 39，103，1931）に表示したるものなり。

(2) 成形疾力 耐火材料試驗片の成形に要したる壓力は $50 \mathrm{~kg} / \mathrm{cm}^{2}, 100 \mathrm{~kg} / \mathrm{cm}^{2}, 150 \mathrm{~kg} / \mathrm{cm}^{2}$ の 3 種を選 び時に $200 \mathrm{~kg} / \mathrm{cm}^{2}$ をも用ひ、是等の成形壓力の大小が後節の試驗結果に及ぼす効果を比䡥することとした り。

（3）燒成溫度 試驗片の燒成の溫度は第二報の結果を參照して $1400^{\circ} \mathrm{C}$ と燒成時間は 2 時間となせり。此 の時間は實際の耐火材料の燒成時間とは此較すべからざる短時間なれども試驗片が直徑 $20 \mathrm{~mm}$, 高さ $30 \mathrm{~mm}$ の小なる圆壔なるを以つて第二報の各種の結果に見てる明らかなる如く等成時間を一定して比較するには其の 影響大ならざることを認めたり。

\section{III. 耐火材料詰驗片の冷間耐壓力の試驗結果}

前節の各種條件を嚴密に守りて試製したる各試驗片の冷間酎熟力を第一報第一及び第二圖（本誌、38，789，

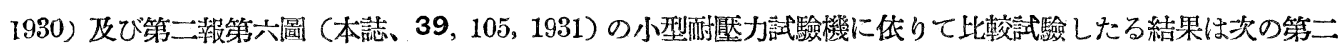

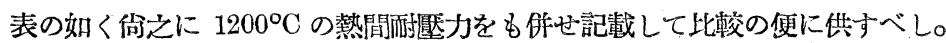

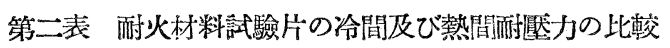

\begin{tabular}{|c|c|c|c|c|c|}
\hline $\begin{array}{l}\text { 武驗片 } \\
\text { 記 號 }\end{array}$ & $\frac{\text { 原 }}{\text { 酥火粘士 }}$ & $\frac{\text { 名 }}{\text { ジャモツト }}$ & $\begin{array}{l}\text { 成形狀力 } \\
\mathrm{kg} / \mathrm{cm}^{2}\end{array}$ & $\begin{array}{c}\text { 冷间耐懕力 } \\
\mathrm{kg} / \mathrm{cm}^{2}\end{array}$ & $\begin{array}{c}1200^{\circ} \mathrm{C} \text { 熱间而煱力 } \\
\mathrm{kg} / \mathrm{cm}^{2}\end{array}$ \\
\hline$A_{10}$ & 復州粘土 & 第三號シヤモット & 100 & 221 & 141 \\
\hline $\mathrm{A}_{25}$ & $"$ & " & " & 333 & 285 \\
\hline $\mathrm{A}_{40}$ & $"$ & " & " & 318 & 245 \\
\hline$B_{10}$ & "I & 第二號シャモツト & " & 235 & 142 \\
\hline $\mathrm{B}_{25}$ & "I & " & "I & 346 & 203 \\
\hline $\mathrm{C}_{10}$ & 三星木節粘士 & 第三號シャモツト & " & 128 & 85 \\
\hline $\mathrm{C}_{25}$ & "I & " & "I & 192 & 173 \\
\hline $\mathrm{C}_{40}$ & " & " & " & 221 & 122 \\
\hline $\mathrm{D}_{10}$ & I" & 第二號シャモット & $" 1$ & 178 & 138 \\
\hline $\mathrm{D}_{25}$ & " & "I & " & 209 & 142 \\
\hline
\end{tabular}

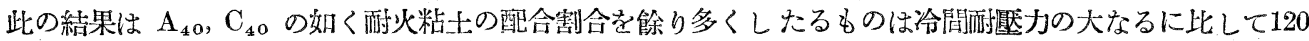
$0^{\circ} \mathrm{C}$ の熱間酎厓力は小となる。故に粘土の配合割合は $40 \%$ の犃く多きことは不可にして約 $25 \%$ 前後を以つ て何れの點よりも優良なる結果を得べきことは既に第二塟に各種の配合割合の試驗結果として報告せるところ とよく一致せり。

\section{IV. 熱間荷重に依る各種物理性の比較}

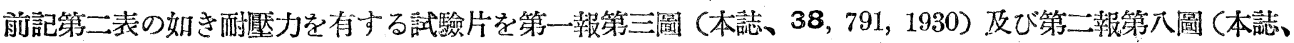
39，169，1931）の熱閌耐壓力の曲線圖を參考に供して前記 $1200^{\circ} \mathrm{C}$ よりは高き $1300^{\circ} \mathrm{C}$ に加熱しながら 10 
$\mathrm{kg} / \mathrm{cm}^{2}$ この荷重をなすこと 30 分の後此の熱間荷重が其の試驗嗢の熱閂荷重の前のものにして受ける各種の 物理性の變化を比較することとしたり。此加熱の方法、荷重の方法等一切の堹も亦前揭第二報第六圖と其の操 作（本誌、39，105-107，1931）に準じたること勿諭なり。而も加熱溫度 $1300^{\circ} \mathrm{C}$ に於ては荷重 $10 \mathrm{~kg} / \mathrm{cm}^{2} 30$ 分は充分大なる効果を與ふべきことは前揭の第一報第三圖及び第四圖、第二武の第入圖より明らかにして又餘 り荷重を大にし叉は時間を長くするときは、熱間荷重後の試驗片の變形著しく試驗片の熱間荷重前のものと各 種の物理性の比較を爲し能はざる迄に到るものあり。次に第三表以下に是等の結果を表示すべし。

(A)シャモットの差異に依るもの 復州粘土を用ひシャモットを第三號（復州粘上より試製したるるの）と 第二號(工場製品)とを使用したるものの比較をなせり。

第三表 復州粘土 $10 \%$ の配合割合の試驗片の熱間荷重前後の物理性の比較

試驗項目

吸水率\%

氣孔率"

見掛比重

嵩比重

$\overbrace{\text { 熱間何重前 同 後 }}^{\mathrm{A}_{\mathbf{1}} \text { (羞粘士、異 }}$

15.6

30.0

2.74

1.92
14.7

28.6

2.73

1.95
$-0.9$

$-1.4$

$-0.01$

$+0.03$

\begin{tabular}{|c|c|c|c|}
\hline \multicolumn{4}{|c|}{$\mathrm{B}_{10}$ (復州稢土、第二號シャモツト) } \\
\hline 爇間衔重前 & 同 & 後 & 美 異 \\
\hline 14.5 & & 13.1. & -1.4 \\
\hline 26.9 & & 23.1 & -3.8 \\
\hline 2.55 & & 2.53 & -0.02 \\
\hline 1.85 & & 1.91 & +0.06 \\
\hline
\end{tabular}

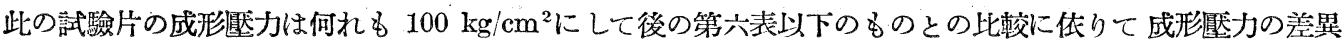
の呈する影響をも知り得べし。此の試驗結果に依れば吸水率、氣孔率、見掛比重、嵩比重の何れに於てもAは Bよりも大なるに比し熱間荷重の前後の變化はBが常にAより大なるを見得べし。秥此の結果は第一報第五表 本誌. 38，792，1930)の市販品 4 種の中の（1）及び（2）と略相一致せるか或は之より優良なる結果を與へた り。

(B) 耐火粘士の量、シャモットの差異等に依るもの 此の第三表に對して耐火粘士を㙝し $25 \%$ の配合割合 とし他の墸條件は前記と全く同一となし 2 種のシャモット、2 種の而火粘土より得らるる 4 種の組久合せの 試驗片に就て比較試驗したる結果を第四及び第五表に示すべし。

第四表 復州粘士 $25 \%$ の配合割合の試驗片の熱間荷重前後の物理性の比較

試驗項目

吸水率\%

氣孔率”

見掛比重

蒿此重

\section{試驗項目}

吸水率\%

氣孔率”

見掛比重

蒿比重

\begin{tabular}{|c|c|c|}
\hline \multicolumn{3}{|c|}{$A_{25}$ (復州粘士、第三號シヤモツト } \\
\hline 間渮重前 & 同 & 差 異 \\
\hline 11.3 & 11.0 & -0.3 \\
\hline 24.1 & 23.1 & -1.0 \\
\hline 2.74 & 2.72 & -0.02 \\
\hline 2.03 & 2.11 & +0.08 \\
\hline
\end{tabular}

\begin{tabular}{ccc}
\multicolumn{3}{c}{$\mathrm{B}_{25}$ (復州粘士、第二號シャモット) } \\
\hline 爇間何重前 & 同 後 & 差 異 \\
12.3 & 12.1 & -0.2 \\
25.0 & 24.2 & -0.8 \\
2.63 & 2.62 & -0.01 \\
1.97 & 2.08 & +0.11
\end{tabular}

第五表 三星木節粘士 $25 \%$ の配合割合の試驗片の熱間荷重前後の物理性の比較

是等の表に見る如く耐火粘士 $25 \%$ の時は第三表と第匹表と比較して吸水率、氣孔率を著しく減少し比重を 增加せり。倘第四表と第五表とを比較すれば同じシャモットに於ても之に配合する耐火粘土に依りて差買著し きものあり。例へば $\mathrm{A}_{25}$ と $\mathrm{C}_{25}$ とを比較すれは復州粘士よりも三星木節粘士の方か吸水率、氣孔率を大に 
比重を小とせり。然るに $\mathrm{B}_{25}$ と $\mathrm{D}_{25}$ とを比較すればとと反對に復州粘土の方が吸水率、氣孔率を大とし比 䨘をも大とせり。斯くの如く 2 種のシャモット、2 種の耐火粘土との組合せに恢る 4 種のシャモット質耐火 材料試驗片つ爇間荷重の前後の各種物理性の比較に传り其の適否を知 ることを得べく此の種の比較試驗は份 次にも行へり。

(C) 耐火粘士の差暴 成形原力の差暴に依るもの、更に第三表乃至第五表と比較し、佔耐火粘土の差異に依 る影響、成形崕力の差異に低る影響を見んが篇め第三表と等しく第三號シャモットにて復州粘士、三星木節粘 土を $10 \% 、 25 \%$ の配合割合にて 其成形堅力を 前記の $100 \mathrm{~kg} / \mathrm{cm}^{2}$ より著しく高め $200 \mathrm{~kg} / \mathrm{cm}^{2}$ として他の 諸條件を同一にしたる時の比較試驗結果は次の第六、第七表の如し。

第六表 復州粘士の $10 \%, 25 \%$ の配合割合の試驗片の熱間荷重前後の物理性の比較

\begin{tabular}{|c|c|c|c|c|c|c|}
\hline \multirow[b]{2}{*}{ 試驗項目 } & \multicolumn{3}{|c|}{$A_{10}$ (復州炶土、第三號シャモット) } & \multicolumn{3}{|c|}{$\mathrm{A}_{25}$ (復州粘土、第三:號シャモツト) } \\
\hline & 熱間荷重前 & 同 & 差 & 熱間荷重前 & 同 & 差 異 \\
\hline 吸 & 15.2 & 14.5 & -0.7 & 11.3 & 10.3 & -1.0 \\
\hline 氮孔率 & 30.8 & 28.5 & -2.3 & 23.7 & 22.0 & -1.7 \\
\hline IL & 2.74 & 2.75 & +0.01 & 2.75 & 2.75 & 0 \\
\hline 嵩比重 & 1.90 & 1.97 & +0.07 & $2 . C 9$ & 2.14 & +0.05 \\
\hline
\end{tabular}

第七表 三星木節粘土 $10 \%, 25 \%$ の配合割合の試驗片の爇留荷重前後の物理性の比較

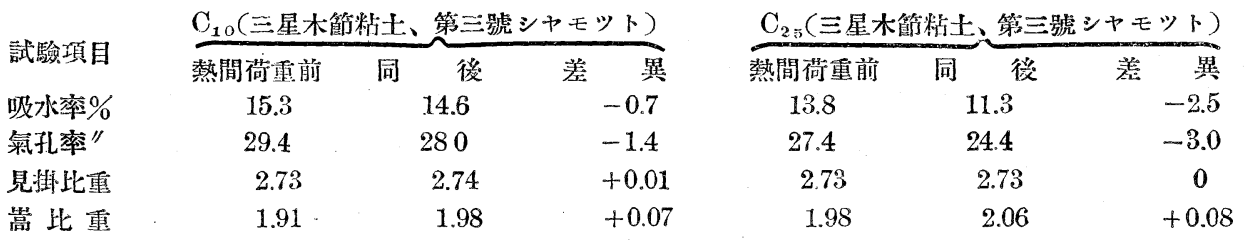

是等の結果、第三表の $\mathrm{A}_{10}$ と第六表の $\mathrm{A}_{10}$, 第四表の $\mathrm{A}_{25}$ と第六表の $\mathrm{A}_{25}$, 第无表の $\mathrm{C}_{25}$ と第六表の $\mathrm{C}_{25}$ 等を各々比較すれば成形娾力が $100 \mathrm{~kg} / \mathrm{cm}^{2}$ のときは何れも吸水率、氣孔率が大となり比重が小となり、 $200 \mathrm{~kg} / \mathrm{cm}^{2}$ のときは全く之に反して吸水率氣孔率共に小に比重大となる。郎ち成形套力の大小か洏秋材料の 熱間荷重前後の物理性に關係するところの大なるを知り得べし。

更に $\mathrm{A}$ と $\mathrm{C}$ とを比较してシャモット第三號を等しくして耐火粘土のみの異なるときの影響を比較すれば 之亦第三、第四、第五表等に於ける耐火粘士学等しくしてシャモットのみを異にせる場合に相對應する影響の あることを知り得べし。

(D) 試驗片の燒成火度を異にし、成形壓力の差異に依るもの 前記の諸實驗には何れも試驗片は $1400^{\circ} \mathrm{C} に$ 燒成したるものなるに對し之より燒成火度を低くし $1350^{\circ} \mathrm{C}$ としたるものに就て同樣に試驗し且つ成形崕力は $50 \mathrm{~kg} / \mathrm{cm}^{2}$ と $150 \mathrm{~kg} / \mathrm{cm}^{2}$ とを選びたり。此の目的はシャモット質耐火材料の成形に其の壓力を充分大なら しめざる場合及び試驗片の燒成火度を充分高からしめざる場合には如何なる結果を招來するかを筧知せんが鹪 めなり。次に第入表を以つて之を示すべし。

第入表 試驗片の然成火度低く、耐火粘土 $10 \% 、 25 \%$ の配合割合の試驗 片の熱間荷重前後の物理性の比輍

\begin{tabular}{|c|c|c|c|c|c|c|}
\hline $\begin{array}{l}\text { 驗試片 } \\
\text { ○記號 }\end{array}$ & $\begin{array}{l}\text { 熱間渮重の } \\
\text { 前後、差黑 }\end{array}$ & $\begin{array}{l}\text { 咸形厴力 } \\
\mathrm{kg} / \mathrm{cm}^{2}\end{array}$ & $\begin{array}{c}\text { 吸水率 } \\
(\%)\end{array}$ & $\begin{array}{c}\text { 氣孔率 } \\
(\%)\end{array}$ & 見捙比重 & 鲎上 \\
\hline & /檨間㻤重前 & $\{50$ & 22.7 & 38.8 & 2.76 & \\
\hline
\end{tabular}




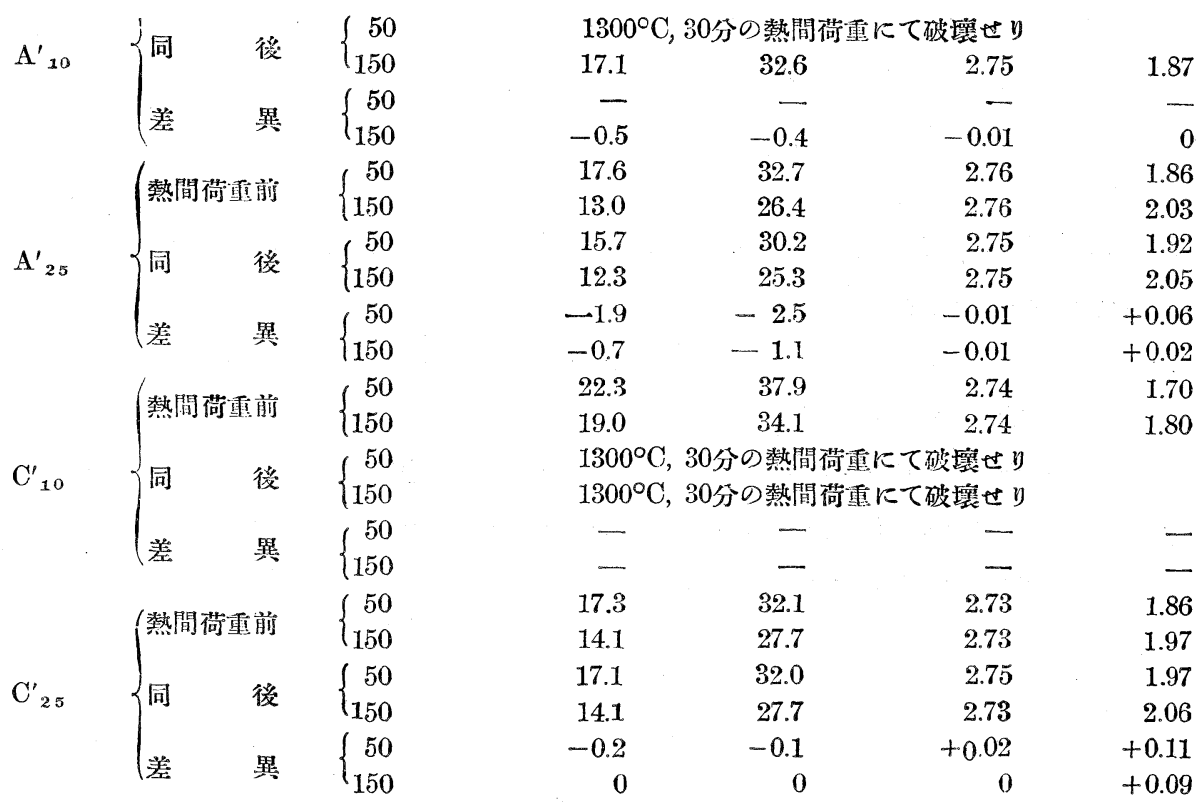

此の結果に依ればシャモット質酎火材档の憢成火度を低くしたるものは耐火材料としての諸種の性狀に於て 著しく劣ることを明らかにし殊に粘士 $10 \%$ の如く少く、成形原力 $50 \mathrm{~kg} / \mathrm{cm}^{2}$ の如く低きるのに於ては 130 $0^{\circ} \mathrm{C} に 10 \mathrm{~kg} / \mathrm{cm}^{2}, 30$ 分間の熱間荷重にすら酎えざるもの多し。又成形篹力が $50 \mathrm{~kg} / \mathrm{cm}^{2}$ と $150 \mathrm{~kg} / \mathrm{cm}^{2}$ との 間には著しき差巽を招來することも明らかなり。

以上第入表の結果はシャモット質耐火材料に於て其の燒成火度の高低は最も重大なる關係を有することを明 らかにし、更に耐火粘土の配合割合、成形㗨力等も亦極めて重要なる關係を有するものなり。勿諭シャモット 及び耐火粘土其のものの性狀が酎火材料の性狀に重大なる關係を有するものなることは云ふを待たず。而も是 等 2 要素の適當なる組久合せの如何も亦重大なる關係を有することは前記の諸表の比較に依りて明らかなり。

\section{$\mathbf{v}$ 總括}

本報に於てはシャモット質酎火材料が熱間荷重に依る各種の物理性の變化に關する比較圾铪をなしたる結果 を報告したるものにして其の穊要を摘錄すべし。

（1）研究試料は 2 種のシャモットと2種の耐火粘土とより其の配合割合を耐火粘士 $10 \%, 25 \%, 40 \%$ に變化 し、成形㗨力を $50 \mathrm{~kg} / \mathrm{cm}^{2}, 100 \mathrm{~kg} / \mathrm{cm}^{2}, 150 \mathrm{~kg} / \mathrm{cm}^{2}, 200 \mathrm{~kg} / \mathrm{cm}^{2}$ 等とし、燒成火度を $1350^{\circ} \mathrm{C}, 1400^{\circ} \mathrm{C}$ 等 として墝成したる試驗片を以つてしたり。

（2）シャモャトの1種は復州粘土より試騟的に製作したるもの、他の 1 種は工場製品なり。又耐火粘土は復 州粘土及び三星木節粘士にして何れも水籍物なり。

（3）㙓間荷重は $1300^{\circ} \mathrm{C}$ に $10 \mathrm{~kg} / \mathrm{cm}^{2}$ の荷重を 30 分阔續け其の前後の各種物理性特に吸水率、氣孔率、 比重等に就て熱間荷重試驗の前後の變化を比較試驗したり。

（4）耐火粘士 $10 \%$ の如く少きものは是等の物理性が熱間荷重の前後に於ける變化著しく、40\% 或は之れ 以上の多量の配合のものは其の耐火粘士の渜火度に支配せらるること多く $1200^{\circ} \mathrm{C}, 1300^{\circ} \mathrm{C}$ の熱間耐诓力を低 下すること多し。從つて $25 \sim 30 \%$ 前後の配合割合のもの最も優良なる結果を與へたり。 
（5）成形壓力が $50 \mathrm{~kg} / \mathrm{cm}^{2}$ の如く低きものも結果は多く不良にして $100 \mathrm{~kg} / \mathrm{cm}^{2}, 150 \mathrm{~kg} / \mathrm{cm}^{2}, 200 \mathrm{~kg} / \mathrm{cm}^{2}$ 等 と增加するにつれ比重を大に、吸水率と㴋孔率とを小に、又熱間荷重前後に於ける是等の數値の變化を小なら Lむ。

（6）シャモット質耐火祆料の燒成火度の高低も亦重大なる影響を有するものにして $1350^{\circ} \mathrm{C}$ より僅かなる高さ の $1400^{\circ} \mathrm{C}$ の燒成に於ても充分有利にして此の附近の燒成溫度の僅小なる上景はシャモット質耐火材料の品質 に重大なる影響を與ふるものなり。

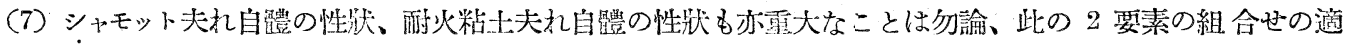
否に依りて熱閒荷重前後の各種物理性の變化に著しき影響を與ふることも明らかに認め得べし。

終りに本研究には三石耐火煉瓦株式會社明石三二氏より多大の便宜を與へられ、且研究者の一人萬波は同社 より派遣せられたるものなり、㷊に謹んで梁く感謝の意を表するものなり。（昭和六年三月一東京帝國大學工 學部應用化學科玨酸監工業化學所究室）

\section{時 計とラン プ}

今より約 300 年前にイタリーにガリレオといふ人が住んでわた。彼も亦アルキメデイス のやうに、絕えず思索に耽つてるた一一彼は寒喛計や、極めて簡單な望遠鏡、顯微鏡を發 明した。斯くして彼の科學上に於け万重大な万發見實に多い。

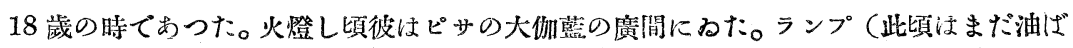
かりを使つてるた) は長い棒で井から吊されてるら。點火器がランプにぶつつかつた

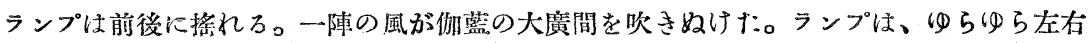
に摇れる。それは恰度振子のやうだつた。彼は、同じ長さの棒にぶらさがつてわろランプ は同じ速さで啮れ、短い棒にぶらさがってわろランプは搖れかげが速いのに氣が付いた。 ゆらけら摇れろランプを注視しつ〉此の少年は非常な興味に打たれ。それまて、此の大伽 藍てランプの摇れろのを目擎した人は、数限りなくめつたのておろ。然し此の現象に關聯 して何ぞ有用な事實を發見して見やうなどと、思ひ浮べだ者は、終いに只の一人もなかつ たのである。ガリレオは自分の室に閉ぢ籠つた、そして實驗に沒頭した——終いに彼は振 子に關する法則を打ち薣てだ。倘研究を進めることに依つて今日のやうな振子時計を發明 Lた。

斯くして、今日吾々の日常生活に於て最も調法な振子時計はその發端を、ピサの大伽藍 のランプに求めることが出來る。しかしえもがリレオの思索癖に負子處多大なること吾 タは忘れてはならない。(Twenty More Famous Stories, Galileo and The Lamps) 